\title{
Ticks parasitizing bats (Mammalia: Chiroptera) in the Caatinga Biome, Brazil
}

\author{
Carrapatos parasitando morcegos (Mammalia: Chiroptera) na Caatinga, Brasil \\ Hermes Ribeiro Luz ${ }^{1}$; Sebastián Muñoz-Leal²*; Juliana Cardoso de Almeida ${ }^{1}$; João Luiz Horacio Faccini'; \\ Marcelo Bahia Labruna ${ }^{2}$
}

\begin{abstract}
${ }^{1}$ Departamento de Parasitologia Animal, Universidade Federal Rural do Rio de Janeiro - UFRRJ, Seropédica, RJ, Brasil
${ }^{2}$ Departamento de Medicina Veterinária Preventiva e Saúde Animal, Faculdade de Medicina Veterinária e Zootecnia, Universidade de São Paulo - USP, Sáo Paulo, SP, Brasil
\end{abstract}

Received September 27, 2016

Accepted October 31, 2016

\begin{abstract}
In this paper, the authors report ticks parasitizing bats from the Serra das Almas Natural Reserve (RPPN) located in the municipality of Crateús, state of Ceará, in the semiarid Caatinga biome of northeastern Brazil. The study was carried out during nine nights in the dry season (July 2012) and 10 nights in the rainy season (February 2013). Only bats of the Phyllostomidae and Mormoopidae families were parasitized by ticks. The species Artibeus planirostris and Carolia perspicillata were the most parasitized. A total of 409 larvae were collected and classified into three genera: Antricola ( $\mathrm{n}=1)$, Nothoaspis $(\mathrm{n}=1)$ and Ornithodoros $(\mathrm{n}=407)$. Four species were morphologically identified as Nothoaspis amazoniensis, Ornithodoros cavernicolous, Ornithodoros fonsecai, Ornithodoros hasei, and Ornithodoros marinkellei. Ornithodoros hasei was the most common tick associated with bats in the current study. The present study expand the distributional ranges of at least three soft ticks into the Caatinga biome, and highlight an unexpected richness of argasid ticks inhabiting this arid ecosystem.
\end{abstract}

Keywords: Ticks, Nothoaspis, Ornithodoros, Antricola, bat, Caatinga.

\section{Resumo}

Neste artigo, os autores relatam carrapatos parasitando morcegos da Serra das Almas Reserva Natural (RPPN), localizada no município de Crateús, Estado do Ceará, no bioma semi-árido da Caatinga no nordeste do Brasil. O estudo foi realizado durante nove noites, na estação seca (julho de 2012) e 10 noites, na estação chuvosa (fevereiro de 2013). Apenas morcegos das famílias Phyllostomidae e Mormoopidae estavam parasitados por carrapatos. As espécies Artibeus planirostris e Carolia perspicillata foram as mais parasitadas. Um total de 409 larvas foram coletadas e classificadas em três gêneros: Antricola $(\mathrm{n}=1)$, Nothoaspis $(\mathrm{n}=1)$ e Ornithodoros $(\mathrm{n}=407)$. Quatro espécies foram identificadas morfologicamente como Nothoaspis amazoniensis, Ornithodoros cavernicolous, Ornithodoros fonsecai, Ornithodoros hasei e Ornithodoros marinkellei. Ornithodoros hasei foi a espécie de carrapato mais comum associada com morcegos no presente estudo. O presente estudo expande a distribuição de, pelo menos, três espécies de argasideos para o bioma Caatinga, e destaca a inesperada riqueza de espécies habitando este árido ecossistema.

Palavras-chave: Carrapatos, Nothoaspis, Ornithodoros, Antricola, morcego, Caatinga.

\section{Introduction}

Ticks are obligate hematophagous ectoparasites and important vectors of agents that cause disease in wild and domestic animals, and humans worldwide (PAROLA \& RAOULT, 2001; COLWELL et al., 2011). The family Argasidae, known as soft ticks, comprises more than 200 species worldwide with 91 representatives in the

*Corresponding author: Sebastián Muñoz-Leal. Departamento de Parasitologia Animal, Universidade Federal Rural do Rio de Janeiro - UFRRJ, BR 465, Km 7, CEP 23890-000, Seropédica, RJ, Brasil. e-mail: seba.munozleal@gmail.com
Neotropics (NAVA et al., 2010; GUGLIELMONE et al., 2010; BARROS-BATTESTI et al., 2013, 2015; VENZAL et al., 2015; MUÑOZ-LEAL et al., 2016a; LABRUNA et al., 2016). While in Brazil Argasidae is represented by 24 species belonging to Antricola, Argas, Nothoaspis, and Ornithodoros genera, at least 19 species belong to the genus Ornithodoros: Ornithodoros brasiliensis Aragão, 1923; Ornithodoros capensis Neumann, 1901; Ornithodoros fonsecai (Labruna \& Venzal, 2009); Ornithodoros guaporensis Nava, Venzal \& Labruna, 2013; Ornithodoros hasei (Schulze, 1935); Ornithodoros 
jul Schulze, 1940; Ornithodoros kohlsi (Guglielmone \& Keirans, 2002); Ornithodoros marinkellei Kohls, Clifford \& Jones, 1969; Ornithodoros mimon Kohls, Clifford \& Jones, 1969; Ornithodoros nattereri Warburton, 1927; Ornithodoros rondoniensis (Labruna, Terrassini, Camargo, Brandão, Ribeiro \& Estrada-Peña, 2008); Ornithodoros rostratus Aragão, 1911; Ornithodoros rudis Karsh, 1880; Ornithodoros setosus Kohls, Clifford \& Jones, 1969; Ornithodoros stageri Cooley \& Kohls, 1941; Ornithodoros talaje (GuérinMéneville, 1849); Ornithodoros faccinii Barros-Battesti, Landulfo \& Luz, 2015; Ornithodoros cavernicolous Dantas-Torres, Venzal \& Labruna, 2012 and Ornithodoros rietcorreai Labruna, Nava \& Venzal, 2016 (GUGLIELMONE et al., 2010; DANTAS-TORRES et al., 2012; BARROS-BATTESTI et al., 2013, 2015; WOLF et al., 2016; LABRUNA et al., 2016). Of this diversity, nine species (47\%) have been associated with bats or bat-frequented caves (LABRUNA \& VENZAL, 2009; LABRUNA et al., 2011; DANTAS-TORRES et al., 2012; BARROS-BATTESTI et al., 2013; MARTINS et al., 2014; MUÑOZ-LEAL et al., 2016b).

The term "Caatinga" refers to the typical xeromorphic vegetation of the semiarid ecosystems in northeastern Brazil that covers an area of approximately $734,478 \mathrm{Km}^{2}$ (MARINHO-FILHO \& SAZIMA, $1998)$, corresponding to $11 \%$ of Brazil's territory. This region includes areas of semi-deciduous and cloud forests, and presents low rainfall and humidity regimes (COSTA et al., 2004). While ticks are associated with bats in other Brazilian biomes (LABRUNA \& VENZAL 2009; LABRUNA et al., 2011; MUÑOZ-LEAL et al., 2016b), to date documented reports of ectoparasites on bats from the Caatinga Biome include only streblid flies (Diptera: Streblidae) (RIOS et al., 2008; BEZERRA et al., 2016) and spinturnicid mites (Acari: Spinturnicidae) (ALMEIDA et al., 2016). In this study we introduce the diversity of ticks parasitizing bats in the Caatinga biome, providing new records of hosts and localities for this understudied group of parasites.

\section{Materials and Methods}

\section{Study site and capture of bats}

The study was carried out during nine nights in the dry season (July 2012) and 10 nights in the rainy season (February 2013) at Serra das Almas Natural Reserve (RPPN), municipality of Crateús, state of Ceará $\left(05^{\circ} 15^{\prime} \mathrm{S}, 41^{\circ} 00^{\prime} \mathrm{W}\right)$. This reserve covers an area of 6,146 hectares and is considered an outpost of the Caatinga Biosphere Reserve (ARAÚJO et al., 2011).

Bats were captured with five to ten mist nets $(36 \mathrm{~mm})$, 6- $18 \mathrm{~m}$ long, $2.5 \mathrm{~m}$ height, placed in existing trails. Sampling period extended for six hours after sunset. Mist nets were examined at intervals of $10 \mathrm{~min}$, and captured bats were kept in individualized and numbered cloth bags. These bags were used only once per day to avoid ectoparasite exchange among collected hosts. Voucher bat specimens were fixed in 10\% formaldehyde and preserved in $70 \%$ alcohol, as previously described (VIZOTTO \& TADDEI, 1973; HANDLEY, 1988), and deposited in the Adriano Lucio Peracchi (ALP) collection, at the Universidade Federal Rural do Rio de Janeiro, Rio de Janeiro, Brazil. Identification of bat species followed the descriptions of Silva et al. (2015) and the taxonomic nomenclature of Nogueira et al. (2014). Accession numbers for bat vouchers are as follow: ALP 10157, 10132, 10138, 10150, 10165, 10167, 10168, 10184 and 10455 .

The capture and collection of specimens was authorized by the Chico Mendes Institute for the Conservation of Biodiversity (ICMBio) of the Brazilian government (license number 32684-1).

\section{Collection and identification of ticks}

Ticks were removed with tweezers and kept in vials containing $70-90 \%$ ethanol for taxonomic identification. In the laboratory, ticks were slide-mounted in Hoyer's medium, and photographed with an Olympus DP70 camera implemented in an Olympus BX40 optical microscope (Olympus Optical Co. Ltd., Japan) for morphological and morphometric analyses. Fully engorged specimens were measured using a stereoscope SteREO Discovery V12 (all measurements are given in $\mathrm{mm}$ ). Ticks were identified at genus level according to Barros-Battesti et al. (2013), and species diagnoses followed Kohls et al. (1969), Jones \& Clifford (1972), and original descriptions of other Neotropical Ornithodorinae (KEIRANS \& CLIFFORD, 1975; NAVA et al., 2010; DANTAS-TORRES et al., 2012). Additional comparisons of immature specimens were made using part of the material deposited at the "Coleção Nacional de Carrapatos" (CNC) of the Faculty of Veterinary Medicine of the University of São Paulo, São Paulo, Brazil.

Molecular analyses were performed in order to confirm morphological identifications of ticks. For this purpose, larvae were individually submitted to DNA extraction by the guanidine isothiocyanate-phenol technique (SANGIONI et al., 2005). DNA of fully engorged larvae was extracted through a small incision in the posterior region of the idiosoma using a $23 \mathrm{G}$ needle. Extracted DNA was subjected to conventional polymerase chain reaction (PCR) targeting a fragment of approximately 460-bp of the mitochondrial 16S rRNA gene, as described elsewhere (MANGOLD et al., 1998). PCR products of the expected size were purified and sequenced using an $\mathrm{ABI}$ automated sequencer (Applied Biosystems/Thermo Fisher Scientific, model ABI 3500 Genetic Analyzer, Foster City, California, USA) with the same primers used in the PCR.

Prevalence of tick infestation (number of infested bats/number of examined bats x 100), and tick mean intensity of infestation (total number of collected ticks/total number of infested bats) were calculated according to Bush et al. (1997).

\section{Results}

A total of 347 bats belonging to six families and 23 species were captured: Phyllostomidae ( $\mathrm{n}=265 ; 16$ species), Mormoopidae ( $n=56 ; 2$ species), Noctilionidae ( $n=2 ; 1$ species), Natalidae $(n=2$; 1 species), Molossidae ( $n=9 ; 1$ species), Vespertilionidae ( $n=13$; 2 species). The species Carollia perspicillata (Linnaeus, 1758) ( $\mathrm{n}=66)$, Artibeus planirostris Spix, $1823(\mathrm{n}=54)$ and Pteronotus parnellii Gray, 1843 ( $\mathrm{n}=43$ ) were the most abundant (SILVA et al., 2015).

Overall, 49 out of 260 (18.8\%) bats, belonging to 12 species of the Phyllostomidae and Mormoopidae families were infested by ticks (Table 1). Of these, Anoura geoffroyi, Artibeus planirostris and 


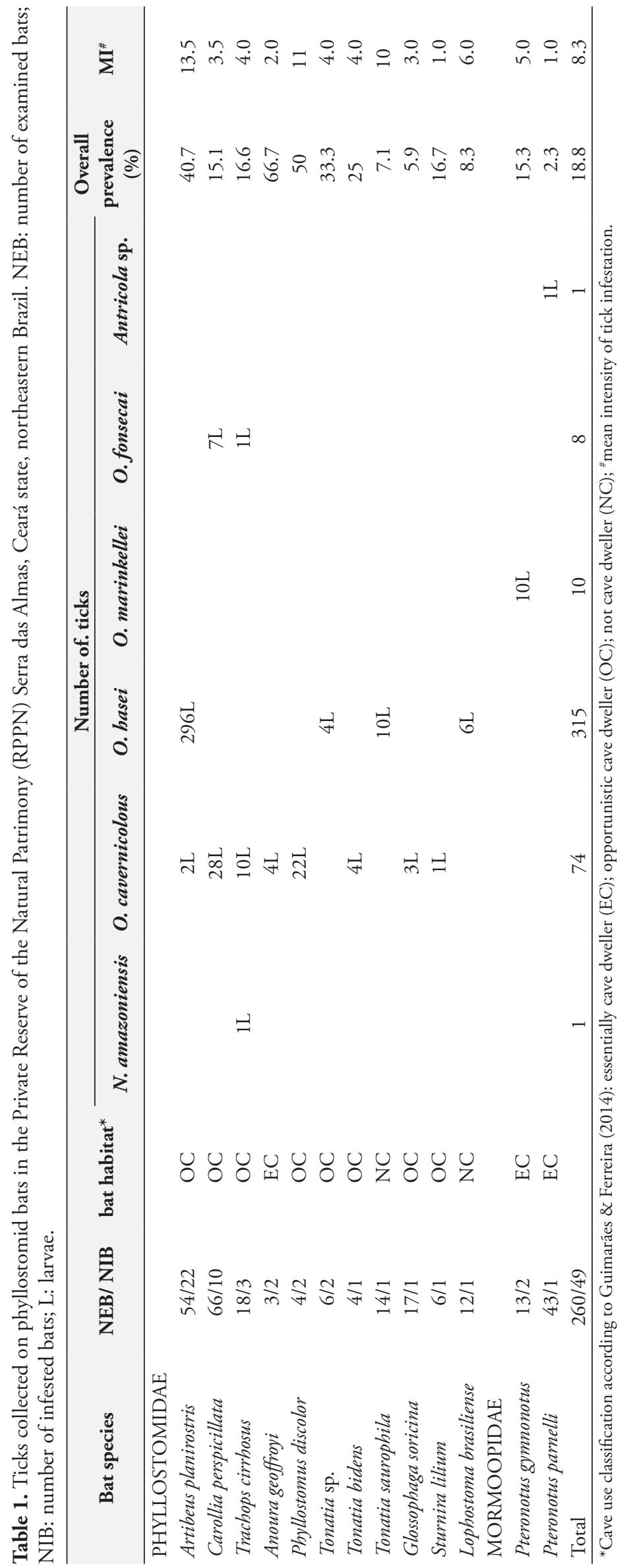


C. perspicillata were the most infested species, with a prevalence of $66.7 \%, 40.7 \%$ and $15.1 \%$, respectively (Table 1 ).

A total of 409 larvae belonging to Antricola, Nothoaspis and Ornithodoros genera were collected (Table 1). The single larva of Antricola was identified to genus level by the presence of three postcoxal setae (KOHLS et al., 1965) (Figure 1). One fully engorged larva of Nothoaspis amazoniensis Nava, Venzal \& Labruna 2010 was identified by the following combination of characters: dorsal plate elongate and triangular; dorsum with 12-13 setae pairs (5-6 anterolateral, 3 central, and 4 posterolateral); venter with 10 pairs of setae; posteromedian setae absent; 3 pairs of sternal setae; 1 pair of post-coxal setae; 5 pairs of circumanal setae; 1 pair of ventral posteromarginal setae and basis capituli pentagonal, following Nava et al. (2010) (Figure 2).
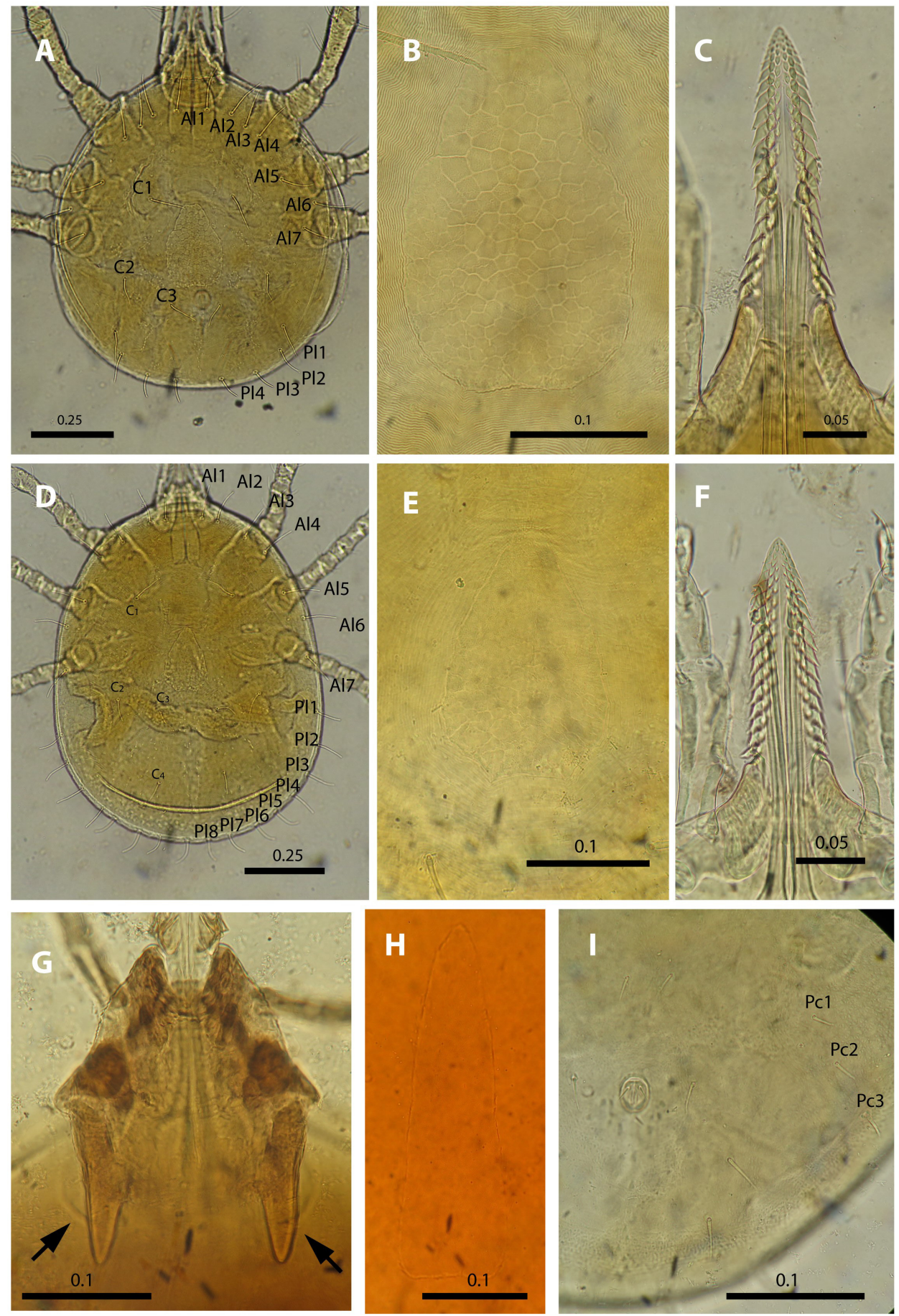

Figure 1. Micrographs of Ornithodoros fonsecai, Ornithodoros hasei, Ornithodoros marinkellei and Antricola sp. larvae. Ornithodoros fonsecai: dorsal idiosoma (A), dorsal plate (B), and hypostome (C). Ornithodoros hasei: dorsal idiosoma (D), dorsal plate (E), and hypostome (F). Ornithodoros marinkellei: cornua-like projection (black arrows) in basis capitulum (G) and dorsal plate (H). Antricola sp.: poscoxal setae (I). Abbreviations: $\mathrm{Al}$, anterolateral seta; $\mathrm{C}$, central seta; $\mathrm{Pl}$, posterolateral seta; Pc, postcoxal seta. 

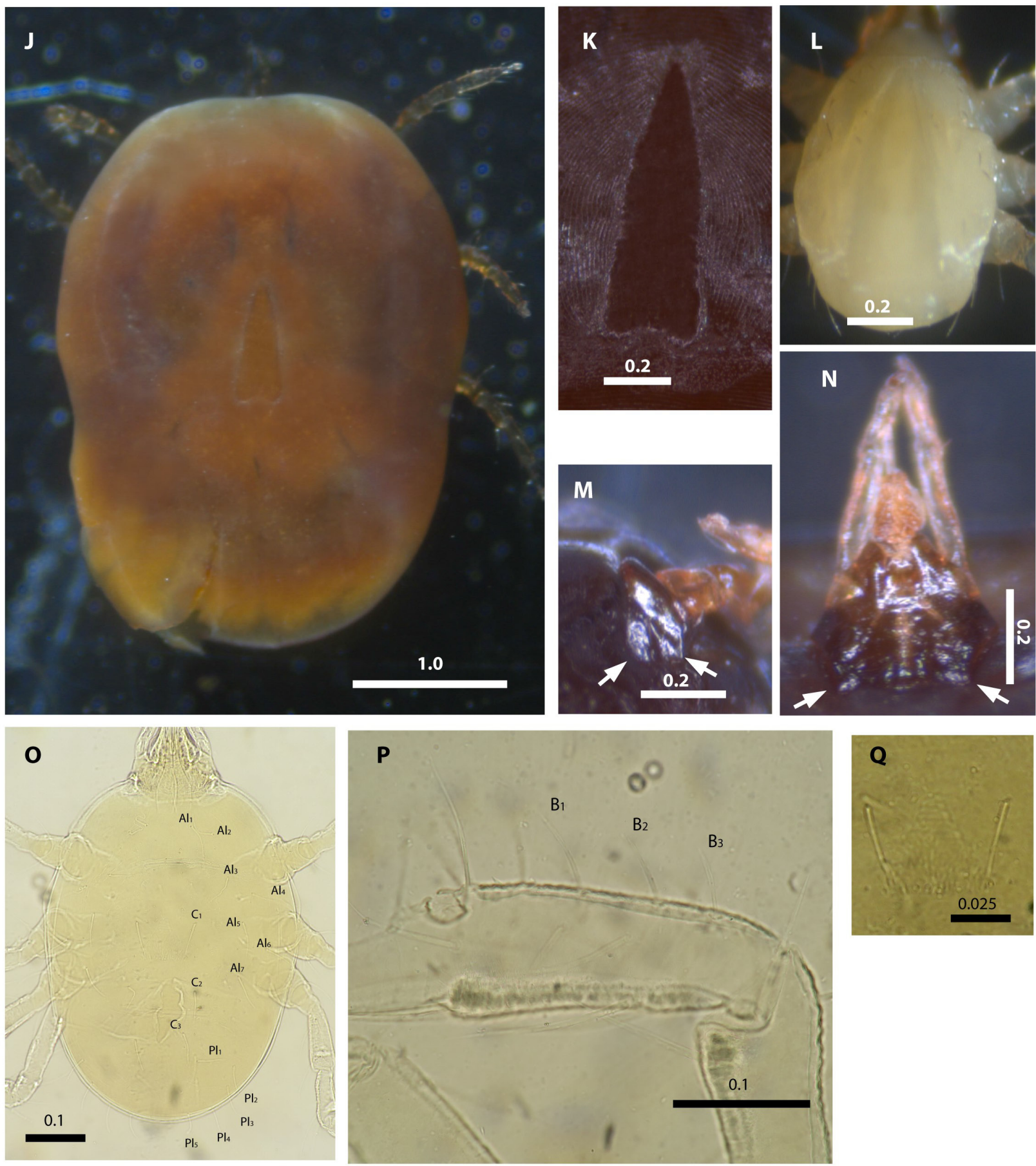

Figure 2. Micrographs of Nothoaspis amazoniensis and Ornithodoros cavernicolous larvae collected in the present study and paratype of N. amazoniensis (NAVA et al., 2010). Nothoaspis amazoniensis: dorsal idiosoma (J), dorsal plate of the collected specimen (K), dorsal plate of paratype. (L), triangular spurs (white arrows) in coxa I (M), auricula-like projections (white arrows) in posterior margin of basis capitulum (N). Ornithodoros cavernicolous: dorsal idiosoma (O), tarsus I (P), and dorsal plate (Q). Abbreviations: Al, anterolateral seta; C, central seta; $\mathrm{Pl}$, posterolateral setae; $\mathrm{B}$, basiventral seta.

Four hundred and seven larvae of the genus Ornithodoros were classified in the following four species: O. cavernicolous $(\mathrm{n}=74)$, O. fonsecai $(\mathrm{n}=8)$, O. hasei $(\mathrm{n}=315)$, and O. marinkellei $(\mathrm{n}=10)$ (Table 1). The morphological characters for the identification of larvae of these species are as follows: 1) O. cavernicolous: dorsal plate with a sub-equilateral triangular shape, dorsum provided with 7 anterolateral, three central and 5 posterolateral pairs of setae, and three pairs of basal setae on tarsus I (DANTAS-TORRES et al., 2012); 2) O. fonsecai: dorsal plate elongate, pyriform, broadest posteriorly, dorsum with 13-14 pairs of setae, with 10-11 dorsolateral pairs and 3 central pairs; hypostome long, pointed apically with dental formula $3 / 3$ in the anterior half, $2 / 2$ posteriorly almost to base; dentition: file 1 with 17 to 18 denticles, 2 with 15 to 17 , and 3 with 9 to 10 (LABRUNA \& VENZAL, 2009); 3) O. hasei: 
dorsal plate pyriform, 15 pairs of dorsolateral setae and 4 pairs of central setae; hypostome apically pointed with 3 rows of denticles (17-19 denticles in row I; 16-17 in row II, and 11-12 in row III); dentition formula $3 / 3$ in the anterior two-thirds and 2/2 towards the base; hypostome arising from a triangular median extension (KOHLS et al., 1965); 4) O. marinkellei: dorsal plate long and narrow, triangular, surface smooth, posterior margin slightly concave; dorsum with 13 pairs of setae, 7 anterolateral, 3 central, and 3 posterolateral, 3 first anterolateral setae short and thick; venter with 8 pairs of setae plus pair on anal valves; posteromedian setae absent; hypostome with dental formula 2/2 throughout length, file 1 with 21 denticles and file 2 with 20-21 denticles, additional denticles around apex, apex pointed, presence of two cornua-like projections in the posterior margin of basis capitulum (LABRUNA et al., 2011) (Figures 1, 2). In addition, morphological identifications of 20 larvae were confirmed by molecular analyses. GenBank accession numbers for the obtained sequences and their respective similarities with other conspecific ticks are shown in Table 2. Attempts to amplify and generate a confident sequence of the mitochondrial 16S rRNA gene from the $N$. amazoniensis were unsuccessful.

Ornithodoros hasei was the most abundant tick followed by O. cavernicolous. O. fonsecai was collected only in C. perspicillata and Trachops cirrhosus, and O. marinkellei only in Pteronotus gymnonotus. Less frequent $N$. amazoniensis and Antricola sp. larvae were only collected in T. cirrhosus and P. parnelli, respectively. The occurrence of co-infestations was observed for $N$. amazoniensis, $O$. cavernicolous and $O$. fonsecai parasitizing T. cirrhosus; $O$. cavernicolous and $O$. hase $i$ parasitizing $A$. planirostris, and $O$. cavernicolous and $O$. fonsecai parasitizing C. perspicillata. Detailed data is presented in Table 1. Overall, the mean intensity of tick infestation was $18.8 \pm 3.6$ ticks per bat, ranging from 1 to 61 ticks per bat (Table 1). Ticks were found attached on the tail membrane, legs, around eyes and mouth of the bats.

Seventeen slide-mounted ticks were deposited at the CNC tick collection under accession numbers CNC-3291, CNC-3353 (O. cavernicolous), CNC-3358 (O. hasei), CNC-3363 (O. fonsecai), CNC-3365 (O. marinkellei) and CNC-3367 (Antricola sp.), and 340 ethanol preserved specimens CNC-3292 ( $N$. amazoniensis), CNC-3354, CNC-3355, CNC-3356, CNC-3357 (O. cavernicolous), CNC-3359, CNC-3360, CNC-3361, CNC-3362 (O. hasei), CNC-3364 (O. fonsecai), and CNC-3366 (O. marinkellei).

\section{Discussion}

In this study, the majority of tick-infested bats constitute species associated with caves, where bats live in colonies or use the caves as opportunistic roosting places (GUIMARÁES \& FERREIRA, 2014).

Ornithodoros hasei was the most common tick found in association with bats from the Caatinga area prospected in the current study, and $A$. planirostris corresponded to the most parasitized host. In a recent study from the Pantanal biome, Muñoz-Leal et al. (2016b) also evidenced high prevalence of $O$. hasei larvae on $A$. planirostris. As suggested by these authors, and reinforced by the data from the Caatinga biome, $A$. planirostris, a bat with wide distribution in Brazil, might play an important role in the biological cycle of $O$. hasei, contributing to the dispersion of this tick.

Ornithodoros cavernicolous, the second most common species, was collected only in cave-roosting bats. This soft tick was described from free-living specimens from caves in the Caatinga biome, and from bat-associated larvae in the Cerrado Biome of central-western Brazil (DANTAS-TORRES et al., 2012). To date only Desmodus rotundus (E. Geoffroy, 1810), Anoura caudifer (E. Geoffroy, 1818), and $C$. perspicillata were reported as hosts of this tick species; therefore, the present study adds seven host species: A. planirostris, Phyllostomus discolor, T. cirrhosus, Tonatia bidens (Spix, 1823), Glossophaga soricina (Pallas, 1766), Sturnira lilium (E. Geoffroy, 1810) and $A$. geoffroyi.

In contrast to $O$. hasei and $O$. cavernicolous, the other two Ornithodoros species collected in this study, O. fonsecai and O. marinkellei, presented low prevalence. From a biogeographic point of view, $O$. fonsecai was exclusively known from a sole cave in the state of Mato Grosso do Sul within the Cerrado biome, and by parasitizing cave-dweller bats such as Peropteryx macrotis (Wagner, 1843) and D. rotundus (E. Geoffroy, 1810) (LABRUNA \& VENZAL, 2009). Here we report new records of this tick in the Caatinga biome, parasitizing the bats $C$. perspicillata and $T$. cirrhosus. The occurrence of $O$. fonsecai in these new localities expands its actual distribution towards the north of Brazil in $\approx 2400 \mathrm{~km}$, and adds two new hosts.

In Brazil, O. marinkellei was previously reported in caves from eastern (LABRUNA et al., 2011) and western (HENRIQUE-SIMÓES et al., 2012) Amazonian biome, in association with three bat species of the genus Pteronotus (LABRUNA et al., 2011). In this way it is not surprising that in the current study larval stages of this tick

Table 2. Mitochondrial 16S rDNA sequences for the analyzed ticks, and their closest similarities in GenBank.

\begin{tabular}{|c|c|c|c|c|}
\hline Tick species & $\begin{array}{c}\text { GenBank - accession } \\
\text { number }\end{array}$ & $\begin{array}{l}\text { Number of larvae } \\
\text { submitted to PCR }\end{array}$ & Host & $\begin{array}{l}\text { Closest similarity in GenBank for the } \\
\text { mitochondrial } 16 \mathrm{~S} \text { rDNA sequence }\end{array}$ \\
\hline O. cavernicolous & KX781697 & 13 & $\begin{array}{l}\text { C. perspicillata, } \\
\text { P. discolor }\end{array}$ & $\begin{array}{l}\text { 100\% (428-pb) O. cavernicolous, Ceará State } \\
\text { (JF714964) }\end{array}$ \\
\hline O. marinkellei & KX781700 & 4 & P. gymnonotus & $\begin{array}{l}\text { 99\% (423/426-pb) O. marinkellei, Brazilian Amazon } \\
\text { (HM582439) }\end{array}$ \\
\hline O. hasei & KX781698 & 2 & A. planirostris & $\begin{array}{l}\text { 99\% (425/427-pb) O. hasei, Mato Grosso do Sul } \\
\text { State (KT894588) }\end{array}$ \\
\hline O. fonsecai & KX781699 & 1 & C. perspicillata & $\begin{array}{l}96 \%(406 / 425-\mathrm{pb}) \text { O. fonsecai, Mato Grosso do Sul } \\
\text { State (KC769597) }\end{array}$ \\
\hline Total & & 20 & & \\
\hline
\end{tabular}


were also collected from the already known host $P$. gymnonotus (LABRUNA et al., 2011); however, at the Caatinga biome. Similarly to $A$. planirostris for $O$. hasei, Pteronotus bats might play an essential role in the biological cycle of $O$. marinkellei, as emphasized in literature (KOHLS et al., 1969; JONES \& CLIFFORD, 1972; VENZAL et al., 2006).

Less abundant collected ticks corresponded to one larva of $N$. amazoniensis and one of Antricola sp.. Previous records of $N$. amazoniensis were documented only from the Amazonian biome and exclusively from the bat P. parnellii (NAVA et al., 2010). Here we report for the first time this tick on T. cirrhosus and in the Caatinga biome. Both, P. parnelli and T. cirrhosus have overlapping distributional ranges and use caves as shelter in the Amazonian, Savannah and Caatinga biomes (BREDT et al., 1999; GUIMARÁES \& FERREIRA, 2014). In this sense, the occurrence of $N$. amazoniensis on either $T$. cirrhosus or $P$. parnellii might be explained by the sharing of caves as roosting places. As both bat species are also distributed in the Savannah, further prospections might find this tick species also in this biome.

All three Antricola species that occurs in Brazil, Antricola guglielmonei Estrada-Peńa, Barros-Battesti \& Venzal 2004, Antricola delacruzi Estrada-Peña, Barros-Battesti \& Venzal 2004, and Antricola inexpectata Estrada-Peña, Barros-Battesti \& Venzal 2004 were described from mature specimens collected in caves from the Sergipe and Ceará states (ESTRADA-PEÑA et al., 2004), located in a transition area between the Atlantic rainforest and the Caatinga biomes. Additional reports included the collection of adults from caves in the Rondônia state within the Amazonian biome (LABRUNA et al., 2008). Although a detailed description of the larvae from both species has not been published, morphological characters of Antricola larvae presented by Cooley \& Kohls (1944), and posteriorly by Kohls et al. (1965), coincide with the general morphology of the larva found parasitizing P. parnelli in the present study. This host-parasite association is not unexpected since both Antricola and Pteronotus bats live in caves (ESTRADA-PENA et al., 2004; GUIMARÃES \& FERREIRA, 2014; LABRUNA et al., 2011), and because Antricola larvae have been reported on Pteronotus bats in the Amazon biome (LABRUNA et al., 2011).

This study provides new geographical ranges for five Brazilian bat-associated soft tick species, expanding the distribution of $N$. amazoniensis, O. marinkellei and O. fonsecai to the Caatinga biome.

\section{Acknowledgements}

We are grateful to the Associação Caatinga for authorization to conduct the fieldwork in the RPPN Serra das Almas. We thank and MSc. Shirley Silva, MSc. Alexandre Cruz, Dr. Patricia Guedes, Dr. Mayara Martins, Ricardo Rocha and Joyce Damascena for the assistance in the field. We also thank and Dr. Daniela Dias and Dr. Adriano Lúcio Peracchi for the identification of bats. MSc. Juliana C. Almeida thanks Dr. N.M.Serra-Freire (in memoriam) for his guidance, FAPERJ for her scholarship. Financial support from CNPq (Process number 470935/2011-1), FAPERJ and CAPES. SML was funded by CONICYT, Programa de Formación de Capital Humano Avanzado, Beca Chile No 72140079.

\section{References}

Almeida JC, Martins MA, Guedes PG, Peracchi AL, Serra-Freire NM. New records of mites (Acari: Spinturnicidae) associated with bats (Mammalia, Chiroptera) in two Brazilian biomes: Pantanal and Caatinga. Rev Bras Parasitol Vet 2016; 25(1): 18-23. PMid:26982558. http://dx.doi. org/10.1590/S1984-29612016005.

Araújo FS, Costa RC, Lima JR, Vasconcelos SF, Girão LC, Sobrinho MS, et al. Floristics and life-forms along a topographic gradient, centralwestern Ceará, Brazil. Rodriguésia 2011; 62(2): 341-366. http://dx.doi. org/10.1590/2175-7860201162210.

Barros-Battesti DM, Landulfo GA, Luz HR, Marcili A, Onofrio VC, Famadas KM. Ornithodoros faccinii n. sp. (Acari: Ixodida: Argasidae) parasitizing the frog Thoropa miliaris (Amphibia: Anura: Cycloramphidae) in Brazil. Parasit Vectors 2015; 8(1): 268. PMid:25963542. http://dx.doi. org/10.1186/s13071-015-0877-3.

Barros-Battesti DM, Ramirez DG, Landulfo GA, Faccini JLH, DantasTorres F, Labruna MB, et al. Immature argasid ticks: diagnosis and keys for Neotropical region. Rev Bras Parasitol Vet 2013; 22(4): 443-456. PMid:24473867. http://dx.doi.org/10.1590/S1984-29612013000400002.

Bezerra RHS, Vasconcelos PF, Bocchiglieri A. Ectoparasites of bats (Mammalia: Chiroptera) in Atlantic forest fragments in north-eastern Brazil. Parasitol Res 2016; 115(10):3759-3765. PMid:27220964. http:// dx.doi.org/10.1007/s00436-016-5137-8.

Bredt A, Uieda W, Magalhães ED. Morcegos cavernícolas da região do Distrito Federal, Centro-Oeste do Brasil (Mammalia, Chiroptera). Rev Bras Zool 1999; 16(3): 731-770. http://dx.doi.org/10.1590/S010181751999000300012 .

Bush AO, Lafferty KD, Lotz JM, Shostak AW. revisited. J Parasitol 1997; 83(4): 575-583. PMid:9267395. http://dx.doi.org/10.2307/3284227.

Colwell DD, Dantas-Torres F, Otranto D. Vector-borne parasitic zoonoses: emerging scenarios and new perspectives. Vet Parasitol 2011; 182(1): 14 21. PMid:21852040. http://dx.doi.org/10.1016/j.vetpar.2011.07.012.

Cooley RA, Kohls GM. The Argasidae of North America, Central America and Cuba. Notre Dame: The University Press; 1944. no. 1. The American midland naturalist. Monograph.

Costa IR, Araújo FS, Lima-Verde LW. Flora e aspectos auto-ecológicos de um encrave de cerrado na Chapada do Araripe, nordeste do Brasil. Acta Bot Bras 2004; 18(4): 759-770. http://dx.doi.org/10.1590/S010233062004000400006.

Dantas-Torres F, Venzal JM, Bernardi LF, Ferreira RL, Onofrio VC, Marcili A, et al. Description of a new species of bat-associated argasid tick (Acari: Argasidae) from Brazil. J Parasitol 2012; 98(1): 36-45. PMid:21955330. http://dx.doi.org/10.1645/GE-2840.1.

Estrada-Peña A, Venzal JM, Barros-Battesti DM, Onofrio VC, Trajano E, Firmino JVL. Three new species of Antricola (Acari: Argasidae) from Brazil, with a key to the known species in the genus. J Parasitol 2004; 90(3): 490-498. PMid:15270091. http://dx.doi.org/10.1645/GE-172R.

Guglielmone AA, Robbins RG, Apanaskevich DA, Petney TN, Estrada-Peńa A, Horak IG, et al. The Argasidae, Ixodidae and Nuttalliellidae (Acari: Ixodida) of the world: a list of valid names. Zootaxa 2010; 2528: 1-28.

Guimarães MM, Ferreira RL. Morcegos cavernícolas do Brasil: novos registros e desafios para conservaçáo. Rev Bras Espeleo 2014; 2(4): 1-34. 
Handley CO Jr. Specimen preparation. In: Kunz TH, Parsons S. Ecological and behavioral methods for the study of bats. Washington: Smithsonian Institution Press; 1988. p. 437-457.

Henrique-Simóes M, Bernardi LFO, Ogrzewalska M, Labruna MB, Ferreira RL. New records of rare Ornithodoros (Acari: Argasidae) species in caves of the Brazilian Amazon. Persian J Acarol 2012; 1(2): 127-135.

Jones EK, Clifford CM. The systematics of the subfamily Ornithodorinae (Acarina: Argasidae). V. a revised key to larval Argasidae of the Western Hemisphere and description of seven new species of Ornithodoros. Ann Entomol Soc Am 1972; 65(3): 730-740. http://dx.doi.org/10.1093/ aesa/65.3.730.

Keirans JE, Clifford CM. Nothoaspis reddelli, New Genus and New Species (Ixodoidea: Argasidae), from a Bat Cave in Mexico. Ann Entomol Soc Am 1975; 68(1): 81-85. http://dx.doi.org/10.1093/aesa/68.1.81.

Kohls GM, Clifford CM, Jones EK. The systematics of the subfamily Ornithodorinae (Acarina: Argasidae). IV. Eight new species of Ornithodoros from the Western Hemisphere. Ann Entomol Soc Am 1969; 62(5): 10351043. http://dx.doi.org/10.1093/aesa/62.5.1035.

Kohls GM, Sonenshine DE, Clifford CM. The systematics of the subfamily Ornithodorinae (Acarina: Argasidae). II. Identification of the larvae of the Western Hemisphere and descriptions of three new species. Ann Entomol Soc Am 1965; 58(3): 331-364. PMid:5835857. http://dx.doi. org/10.1093/aesa/58.3.331.

Labruna MB, Nava S, Marcili A, Barbieri ARM, Nunes PH, Horta $\mathrm{MC}$, et al. A new argasid tick species (Acari: Argasidae) associated with the rock cavy, Kerodon rupestris Wied-Neuwied (Rodentia: Caviidae), in a semiarid region of Brazil. Parasit Vectors 2016; 9 (1): 511. PMid:27655282. http://dx.doi.org/10.1186/s13071-016-1796-7.

Labruna MB, Nava S, Terassini FA, Onofrio VC, Barros-Battesti DM, Camargo LMA, et al. Description of adults and nymph, and redescription of the larva, of Ornithodoros marinkellei (Acari: Argasidae), with data on its phylogenetic position. J Parasitol 2011; 97(2): 207-217. PMid:21506769. http://dx.doi.org/10.1645/GE-2620.1.

Labruna MB, Terassini FA, Camargo LMA, Brandão PE, Ribeiro AF, Estrada-Peña A. New reports of Antricola guglielmonei and Antricola delacruzi in Brazil, and a description of a new argasid species (Acari). J Parasitol 2008; 94(4): 788-792. PMid:18576796. http://dx.doi. org/10.1645/GE-1447.1.

Labruna MB, Venzal JM. Carios fonsecai sp. nov. (Acari, Argasidae), a bat tick from the central-western region of Brazil. Acta Parasitol 2009; 54(4): 355-363. http://dx.doi.org/10.2478/s11686-009-0051-1.

Mangold AJ, Bargues MD, Mas-Coma S. Mitochondrial 16S rRNA sequences and phylogenetic relationships of species of Rhipicephalus and other tick genera among Metastriata (Acari: Ixodidae). Parasitol Res 1998; 84(6): 478-484. PMid:9660138. http://dx.doi.org/10.1007/ s004360050433.

Marinho-Filho J, Sazima I. Brazilian bats and conservation biology: a first survey. In: Kunz TH, Racey PA. Bat biology and conservation. Washington: Smithsonian; 1998. p. 282-294.
Martins TF, Venzal JM, Terassini FA, Costa FB, Marcili A, Camargo LM, et al. New tick records from the state of Rondônia, western Amazon, Brazil. Exp Appl Acarol 2014; 62(1): 121-128. PMid:23975565. http:// dx.doi.org/10.1007/s10493-013-9724-4.

Muñoz-Leal S, Eriksson A, Santos CF, Fischer E, Almeida JC, Luz $\mathrm{HR}$, et al. Ticks infesting bats (Mammalia: Chiroptera) in the Brazilian Pantanal. Exp Appl Acarol 2016b; 69(1): 73-85. PMid:26912332. http:// dx.doi.org/10.1007/s10493-016-0026-5.

Muñoz-Leal S, Venzal JM, González-Acuña D, Nava S, Lopes MG, Martins TF, et al. A new species of Ornithodoros (Acari: Argasidae) from desert areas of northern Chile. Ticks Tick Borne Dis 2016a; 7(5): 901910. PMid:27132517. http://dx.doi.org/10.1016/j.ttbdis.2016.04.008.

Nava S, Venzal JM, Terassini FA, Mangold AJ, Camargo LM, Labruna MB. Description of a new argasid tick (Acari: Ixodida) from bat caves in Brazilian Amazon. J Parasitol 2010; 96(6): 1089-1101. PMid:21158616. http://dx.doi.org/10.1645/GE-2539.1.

Nogueira MR, Lima IP, Moratelli R, Tavares VC, Gregorin R, Peracchi AL. Checklist of Brazilian bats, with comments on original records. Check List 2014; 10(4): 808-821. http://dx.doi.org/10.15560/10.4.808.

Parola P, Raoult D. Ticks and tickborne bacterial diseases in humans: an emerging infectious threat. Clin Infect Dis 2001; 32(6): 897-928. PMid:11247714. http://dx.doi.org/10.1086/319347.

Rios GFP, Sá-Neto RJ, Graciolli G. Fauna de Dípteros Parasitas de Morcegos em uma área de Caatinga do nordeste do Brasil. Chiroptera Neotrop 2008; 14(1): 339-345.

Sangioni LA, Horta MC, Vianna MCB, Gennari SM, Soares RM, Galvão MAM, et al. Rickettsial infection in animals and Brazilian spotted fever endemicity. Emerg Infect Dis 2005; 11(2): 265-270. PMid:15752445. http://dx.doi.org/10.3201/eid1102.040656.

Silva SSP, Dias D, Martins MA, Guedes PG, Almeida JC, Cruz AP, et al. Bats (Mammalia: Chiroptera) from the caatinga scrublands of the Crateús region, Northeastern Brazil, with new records for the state of Ceará. Mastozool Neotrop 2015; 22(2): 335-348.

Venzal JM, González-Acuña D, Muñoz-Leal S, Mangold AJ, Nava S. Two new species of Ornithodoros (Ixodida; Argasidae) from the Southern Cone of South America. Exp Appl Acarol 2015; 66(1): 127-139. PMid:25702203. http://dx.doi.org/10.1007/s10493-015-9883-6.

Venzal JM, Onofrio VC, Barros-Battesti DM, Arzua M. Família Argasidae: características gerais, comentários e chave para gênero e espécies. In: Barros-Battesti DM, Arzua M, Bechara GH. Carrapatos de importância medico-veterinária na regiāo Neotropical. São Paulo: Vox; ICTTD-3; Butantan; 2006. p. 13-27.

Vizotto LD, Taddei VA. Chave para determinação de quirópteros brasileiros. Revista da Faculdade de Filosofia Ciências e Letras de São José do Rio Preto. 1973: 1-72.

Wolf RF, Aragona M, Muñoz-Leal S, Pinto LB, Melo ALT, Braga IA, et al. Novel Babesia and Hepatozoon agents infecting non-volant small mammals in the Brazilian Pantanal, with the first record of the ticks Ornithodoros guaporensis in Brazil. Ticks Tick Borne Dis 2016; 7(3): 449456. PMid:26782931. http://dx.doi.org/10.1016/j.ttbdis.2016.01.005. 